\title{
IMPLEMENTASI KEBIJAKAN \\ PENCEGAHAN DAN PENGENDALIAN KEBAKARAN HUTAN DAN LAHAN DI KAWASAN HUTAN GAMBUT KABUPATEN MUARO JAMBI OLEH BADAN PENANGGULANGAN BENCANA DAERAH (BPBD) PROVINSI JAMBI
}

\author{
Oleh \\ Muhammad Makky Yahusafat ${ }^{1}$, \\ Etin Indrayani ${ }^{2}$, Kusworo ${ }^{3}$ \\ 1) Pemerintah Provinsi Jambi \\ Program Magister Terapan Studi Pemerintahan Daerah Institut Pemerintahan Dalam Negeri \\ myahusafat@yahoo.com \\ 2,3) Institut Pemerintahan Dalam Negeri
}

\begin{abstract}
Tambi Provincial Government together with DPRD Enacted Regional Regulation No. 2 of 2016 concerning Prevention and Control of Forest and Land Fires in Jambi Province. With this legal basis, the Jambi provincial government can carry out the prevention and control of forest and land fires coordinated by the Jambi Province Regional Management Agency (BPBD) with the availability of personnel, facilities, and costs. Therefore, researchers conducted research on the implementation of prevention and control of forest and peatland fires in Muaro Jambi Regency by BPBD Jambi Province.

This study uses implementation theory according to Van Metter and Van Horn. This research uses descriptive caulitative research method with data collection techniques through interviews, documentation and observation.

The results of this study indicate that the Prevention and Control Standards have not been met, Lack of human resources and infrastructure and costs, there is no technical SOP for prevention and control, communication between organizations is not optimal, the attitude of the implementers is still limited due to lack of facilities, social and political support is quite supportive. The obstacles are road access to peat forest areas that are not available, then limited availability of resources and community awareness of the environment and practical land clearing. Then several strategies were proposed, namely increasing cooperation between the task force and the community, organizing training for forest and land fires volunteers, increasing budget proposals and consolidating/strengthening prevention, coordination to the village level.
\end{abstract}

Keywords: policy implementation, karhutla, peat forest, $B P B D$, prevention and control

\section{AbSTRAK}

Demerintah Provinsi Jambi bersama DPRD Menetapkan Peraturan Daerah Nomor 2 Tahun 2016 tentang Pencegahan dan pengendalian Kebakaran hutan dan lahan di provinsi jambi. Dengan adanya dasar hukum tersebut pemerintah Provinsi Jambi dapat melakukan pencegahan dan pengendalian kebakaran hutan dan lahan yang dikoordinasikan Badan Penanggulangan 
Daerah (BPBD) Provinsi Jambi dengan ketersediaan personel, fasilitas, biaya yang ada. Oleh karena itu peneliti melakukan penelitian tentang implementasi pencegahan dan pengendalian kebakaran hutan dan lahan gambut Kabupaten Muaro Jambi oleh BPBD Provinsi Jambi.

Penelitian ini menggunakan teori implementasi menurut Van Metter dan Van Horn. Penelitian ini menggunakan metode penelitian kualitatif deskriptif dengan teknik pengumpulan data melalui wawancara, dokumentasi dan observasi.

Hasil penelitian ini menunjukkan bahwa Standar Pencegahan dan Pengendalian belum terpenuhi, Kekurangan sumber daya manusia dan sarana prasarana serta biaya, tidak adanya SOP teknis pencegahan dan pengendalian, komunikasi antarorganisasi belum maksimal, sikap pelaksana masih terbatas karena kekurangan fasilitas, dukungan sosial masyarakat dan politik cukup mendukung. Adapun hambatan-hambatannya, yaitu akses jalan ke kawasan hutan gambut yang tidak tersedia, kemudian keterbatasan ketersediaan sumber daya dan masih terdapatnya kesadaran masyarakat terhadap lingkungan dan pembukaan lahan yang di lakukan secara praktis. Kemudian beberapa strategi yang diusulkan, yaitu Meningkatkan kerja sama antara satgas dengan masyarakat, Mengadakan pelatihan kepada relawan karhutla, Meningkatkan usulan anggaran dan Konsolidasi/penguatan pencegahan, koordinasi sampai tingkat desa.

Kata kunci: implementasi kebijakan, karhutla, hutan gambut, BPBD, pencegahan dan pengendalian

\section{PENDAHULUAN}

Dencegahan dan penanggulangan bencana merupakan hal penting yang harus diselenggarakan oleh pemerintah melaluilembaga yang telah dibentuk baik pada pemerintah pusat dan pemerintah daerah provinsi dan pemerintah kota/ kabupaten. Sesuai dengan amanah Undang-Undang Nomor 23 Tahun 2014 tentang pemerintahan daerah bahwa dalam peraturan tersebut menyebutkan pembagian kewenangan pemerintah daerah provinsi dan pemerintah daerah kabupaten salah satunya dalam penanggulangan bencana.

Provinsi jambi merupakan salah satu daerah yang berpotensi rawan kebakaran hutan dan lahan, karena daerah tersebut banyak memiliki kawasan hutan gambut. Bencana kebakaran hutan dan lahan di provinsi Jambi mengalami peningkatan luas kebakaran hutan dan lahan pada 2019, peningkatan luas lahan kebakaran tersebut mencapai tiga puluh kali lipat dari pada sebelumnya. Berdasarkan data dari Sipongi. luas kebakaran hutan dan lahan yang terjadi di Provinsi Jambi sebagai berikut.
Tabel 1 Luas Kebakaran Hutan dan Lahan Provinsi Jambi 2014-2019

\begin{tabular}{ccc}
\hline No & Tahun & $\begin{array}{r}\text { Luas Kebakaran Hutan } \\
\text { Lahan (Ha) }\end{array}$ \\
\hline 1. & 2014 & dan \\
2. & 2015 & $115.670,61$ \\
3. & 2016 & $8.281,25$ \\
4. & 2017 & 109,17 \\
5. & 2018 & $1.577,75$ \\
6. & 2019 & $39.638,00$ \\
\hline
\end{tabular}

Sumber: sipongi.menlhk.go.id

Kebakaran hutan dan lahan yang terjadi mengakibatkan terganggunya kesehatan. Adapun akibat kesehatan yang terjadi pada masyarakat, yaitu pada 2019 jumlah warga Jambi yang terserang ISPA selama puncak bencana asap Agustus-September mencapai 63.554 orang. Sebagian besar penderita ISPA tersebut berasal dari anak-anak hingga remaja. Bahkan terganggunya aktivitas penerbangan untuk keberangkatan ke luar daerah provinsi, kemudian berdasarkan berita media online detiknews pada Rabu, 16 Oktober 2019 mengatakan bahwa tak hanya sekolah, kampus universitas negeri pun juga diliburkan, hal ini tentu dapat mengganggu aktivitas belajar para pelajar siswa/siswi 
dan mahasiswa. Bukan hanya itu akibat kerusakan hutan di Provinsi Jambi saat ini sudah masuk kategori melampaui ambang batas. Kerusakan hutan yang sangat luas di daerah itu telah menimbulkan kerugian negara hingga Rp12 triliun.

Bukan hanya itu akibat karhutla menyebabkan langit di muaro jambi membuat langit menjadi merah, berdasarkan Badan Meteorologi, Klimatologi, dan Geofisika (BMKG) membuat fenomena itu disebabkan oleh jelaga atau partikel debu polutan berukuran sangat kecil sudah mencapai atmosfer dan sangat berbahaya jika di hirup.

\section{METODE PENELITIAN}

MetodePenelitianyang digunakanadalah metode penelitian kualitatif dengan teknik cara menentukan informan, yaitu purposive sampling dan teknik pengumpulan data dengan menggunakan teknik wawancara, observasi dan dokumentasi dengan teknik analisis data dengan reduksi data, displai data dan Conclusion Drawing/verification.

\section{KAJIAN PUSTAKA}

Dalam penelitian ini peneliti menggunakan teori implementasi kebijakan menurut van meter dan van horn dengan enam variabel, yaitu standar dan sasaran kebijakan/ukuran dan tujuan kebijakan, sumber daya, karakteristik organisasi pelaksana, komunikasi antarorganisasi, sikap para pelaksana dan dukungan sosial, ekonomi dan politik. Dalam penelitian ini juga menggunakan teori strategi SWOT (strength, waekness, opportunities and threats).

\section{HASIL DAN PEMBAHASAN}

\section{Standar dan Sasaran Kebijakan}

Hasil wawancara bahwa BPBD mempunyai standar dan sasaran pencegahan dan pengendalian BPBD Provinsi Jambi dalam menangani kebakaran hutan dan lahan khususnya di lahan gambut yang ada di Kabupaten Muaro Jambi, yaitu adanya peraturan Menteri Lingkungan Hidup dan kehutanan nomor P.32/MenLHK/Setjen/ Kum.1/3/2016 tentang pengendalian kebakaran hutan dan lahan dan peraturan daerah Nomor 2 Tahun 2016 tentang pencegahan dan pengendalian kebakaran hutan dan lahan, kemudian hasil observasi peneliti juga melihat bahwa BPBD Provinsi Jambi juga memiliki standar dan sasaran yang jelas, yaitu peraturan Menteri Lingkungan Hidup dan kehutanan nomor P.32/MenLHK/Setjen/Kum.1/3/2016 tentang pengendalian kebakaran hutan dan lahan dan peraturan daerah Nomor 2 Tahun 2016 tentang pencegahan dan pengendalian kebakaran hutan dan lahan, namun belum dapat dipenuhi karena keterbatasan anggaran.

Berdasarkan hasil analisis tersebut bahwa pada aspek standar dan sasaran pencegahan dan pengendalian kebakaran hutan dan lahan sudah jelas dan terukur, namun standar yang telah ditetapkan tersebut belum bisa diimplementasikan dengan baik karena keterbatasan anggaran yang dimiliki BPBD Provinsi Jambi.

\section{Sumber Daya}

Pada aspek sumber daya terlihat masih kurangnya jumlah personel pemadam kebakaran hutan dan lahan, sarana dan prasarana seperti peralatan pemadam dan alat angkutan juga masih kurang jika dibandingkan dengan luasnya wilayah hutan gambut di Kabupaten Muaro Jambi yang mencapai 39.638 Hektare, jumlah personel yang hanya 4.770 personel dan peralatan yang sangat sedikit. Bahkan alat angkutan hanya sedikit dan sarana prasarana belum memenuhi standar peraturan menteri Lingkungan Hidup dan kehutanan nomor P.32/MenLHK/Setjen/Kum.1/3/2016 tentang pengendalian kebakaran hutan 
dan lahan, bukan hanya itu sumber daya anggaran pun terbilang sedikit dibandingkan dengan beban kerja dan kebutuhan dan mengalami kekurangan untuk melakukan pencegahan kebakaran hutan dan lahan. Keterbatasan anggaran tersebut membuat BPBD Provinsi Jambi sulit untuk menambah jumlah personel dan sarana dan prasarana.

\section{Karakteristik Organisasi Pelaksana}

Pada aspek karakteristik organisasi bahwa agen pelaksana proyek itu harus berkarakteristik keras dan ketat pada aturan serta sanksi hukum. Oleh karena itu bahwa dapat dikatakan implementasi pada aspek karakteristik organisasi, yaitu berupa SOP teknis pemadaman kebakaran hutan dan lahan di BPBD Provinsi Jambi belum ada dan masih menyusun SOP teknis pemadaman kebakaran hutan dan lahan dan saat ini baru ada mekanisme penanganan kebakaran dan untuk prosedur tindakan lapangan masih mengacu berdasarkan ilmu pelatihan saja dan belum ditetapkan SOP dari BPBD Provinsi Jambi.

\section{Sikap Para Pelaksana}

Pada aspek sikap para pelaksana dapat dikatakan baik, dilihat dari kesiapsiagaan para pelaksanayang selalu ada di posko dalam rangka pencegahan dan penanggulangan kebakaran hutan dan lahan.

\section{Komunikasi Antarorganisasi dan Kegiatan-Kegiatan pelaksana}

Pada aspek rapat-rapat koordinasi dapat dikatakan telah dilaksanakan oleh pemerintah provinsi Jambi bersama Satuan Tugas gabungan kebakaran hutan dan lahan. Rapat-rapat koordinasi tersebut telah dilaksanakan beberapa kali oleh BPBD dan Instansi terkait dan TNI serta Polri.

\section{Lingkungan Sosial, Ekonomi dan Politik}

Pada aspek sosial masyarakat dapat dikatakan mendukung pencegahan dan pengendalian kebakaran hutan dan lahan gambut di Muaro Jambi, namun pada aspek ekonomi masih terdapat beberapa orang yang menjadi tersangka pembakaran hutan dan lahan dengan alasan untuk penghematan biaya pembukaan lahan, yang mana BPBD Provinsi Jambi mengalami kekurangan anggaran untuk melakukan sosialisasi ke masyarakat untuk tidak melakukan pembakaran hutan dan lahan. Kemudian pada aspek politik dengan adanya perda Nomor 2 Tahun 2016 menunjukkan bahwa adanya dukungan politik dari DPRD Provinsi Jambi sebagai lembaga politik daerah, namun pada aspek anggaran masih belum memenuhi kebutuhan BPBD.

\section{Faktor-Faktor Penghambat}

1. Medan yang Sulit di Jangkau oleh Satgas Darat

Keadaan hutan tersebut memang berada jauh dari lokasi tempat warga dengan keadaan jalan seadanya. Bahkan akses menuju ke lokasi sangat sulit dengan kondisi lebatnya pepohonan ranting.

2. Sarana dan Prasarana alat dan perlengkapan terbatas

Jumlah alat yang dimiliki oleh Provinsi Jambi terhadap luas kawasan wilayah hutan daratan seluas 4.882 .857 ha, yaitu di antaranya alat pemompa dengan busa berjumlah 132 unit, kemudian 100 pompa pemadam PO. Tentunya data tersebut menunjukkan masih banyaknya kekurangan alat maupun sarana dalam pencegahan dan pengendalian kebakaran hutan yang dimiliki oleh BPBD Provinsi Jambi.

3. Keterbatasan anggaran

Anggaran yang dimiliki oleh BPBD Provinsi Jambi belum cukup memadai dalam memenuhi kebutuhan dalam pencegahan dan pengendalian kebakaran hutan di provinsi Jambi terutama di Kabupaten Provinsi 
Jambi. Faktor anggaran ini juga yang menyebabkan sarana dan prasarana yang dimiliki masih belum maksimal.

4. Rendahnya Kesadaran Masyarakat

Kebakaran yang terjadi di kabupaten Muara Jambi memang ada yang disebabkan dengan disengajanya oleh beberapa oknum, oknum-oknum tersebut sudah ditangkap dan di tindak dengan mendapatkan sanksi dan hukuman yang sudah ditentukan.

5. Sumber daya Manusia

Luasnya kawasan hutan yang terbakar di Kabupaten Muaro Jambi tidak sebanding dengan kekuatan personel yang di turunkan di lapangan. sehingga memang kekuatan jumlah personel menjadi salah satu sebab dari belum maksimalnya hasil yang didapatkan dari tim gabungan di lapangan sehingga menyebabkan dampak terhadap lingkungan masyarakat terutama terhadap kesehatan masyarakat. Oleh sebab itu pencegahan dini dan pengendalian dalam penanggulangan kebakaran lahan gambut sangat diperlukan menghindari kerusakan-kerusakan alam demi terciptanya lingkungan yang bersih dan bebas asap.

Strategi yang sebaiknya digunakan untuk implementasi kebijakan pencegahan dan pengendalian kebakaran hutan dan lahan oleh Badan Penanggulangan Bencana Daerah (BPBD) Provinsi Jambi di Kawasan Hutan Gambut tampak seperti pada matriks SWOT tabel 2.

Tabel 2. Matriks SWOT Strategi Implementasi Kebijakan Pencegahan dan Pengendalian Karhutla oleh BPBD Prov. Jambi di Kawasan Hutan Kab. Muaro Jambi

\section{Faktor Internal}

Faktor Eksternal

\section{Kekuatan (Strengths)}

1. Adanya Permenhut 32 no tahun 2016 mengenai pencegahan pengendalian kebakaran hutan;

2. Adanya perda No 2 Tahun 2016 tentang Pencegahan dan pengendalian kebakaran Hutan dan lahan di Provinsi Jambi;

3. Tersedia sumber daya Manusia;

4. Tersedia Alat perlengkapan;

5. Adanya Satgas Karhutla;

6. Adanya beberapa personel yang mengikuti pelatihan;.

\section{Kelemahan (Weakness)}

1. Kurangnya Anggaran yang di alokasikan;

2. Kurangnya jumlah personel Satgas karhutla;

3. Kurangnya sarana prasarana;

4. Sedikit personel yang memiliki sertifikasi pelatihan;

5. Tidak adanya Standar Operasional Prosedur secara teknis mengenai pengendalian kebakaran;

6. Kekurangan embung dan kanal di sekitar kawasan lahan gambut; 


\section{Peluang (Opportunities)}

1. Adanya aplikasi berbasis pemantau titik Api (LAPAN);

2. Adanya pelatihan-pelatihan yang diadakan pemerintah Provinsi dan Pemerintahan Pusat;

3. Adanya bantuan sarana dan prasarana dari pusat;

4. Adanya bantuan tenaga dari masyarakat;

5. Ketersediaan apbd;

\section{Ancaman (Threats)}

1. Luas nya kawasan hutan Gambut;

2. Kesadaran masyarakat yang masih rendah terhadap lingkungan;

3. Pembukaan lahan masyarakat atau perusahaan yang masih menggunakan carayang praktis, yaitu dengan membakar lahan;

4. Ke depan kebakaran hutan gambut yang mencapai 2-8 meter;

5. Mudahnya terbakar lahan Gambut oleh sinar matahari;

6. Masih banyak binatang liar di kawasan gambut;.

7. Medan akses menuju lokasi kawasan hutan masih terbatas;

8. Gangguan jaringan internet dan jaringan listrik yang tidak stabil;

\section{Strategi SO}

1. Mengadakan dan mengikutsertakan personel pembinaan dan pelatihan.

2. Meningkatkan kerja sama antara satgas dengan masyarakat.

3. Mengadakan pelatihan kepada relawan karhutla

\section{Strategi Wo}

1. Meningkatkan usulan anggara.

2. Meningkatkan pelatihan personel yang belum memiliki sertifikasi;

3. Meningkatkan usulan peralatan ke pemerintah pusat;

\section{Strategi WT}

\section{Strategi ST}

1. Meningkatkan penegakan

1. Melaksanakan

forum hukum

komunikasi dan koordinasi

2. Memenuhi standar peraturan Permenhut. dengan perangkat daerah terkait

2. Konsolidasi/penguatan pencegahan, koordinasi sampai tingkat desa.

Sumber: Diolah Peneliti, 2020

Tabel 2 Isu Strategis yang Ditetapkan Berdasarkan Kategori Kestrategisannya

\begin{tabular}{clcc}
\hline No & \multicolumn{1}{c}{ Isu Strategis } & Skor & Kriteria Isu \\
\hline 1 & $\begin{array}{l}\text { Mengadakan dan mengikutsertakan personel pembinaan } \\
\text { dan pelatihan. }\end{array}$ & cukup strategis \\
\hline
\end{tabular}




\begin{tabular}{|c|c|c|c|}
\hline 2 & Meningkatkan kerja sama antara satgas dengan masyarakat. & 33 & sangat strategis \\
\hline 3 & Mengadakan pelatihan kepada relawan karhutla & 31 & sangat strategis \\
\hline 4 & Meningkatkan penegakan hukum & 22 & cukup strategis \\
\hline 5 & Memenuhi standar peraturan Permenhut. & 30 & cukup strategis \\
\hline 6 & Meningkatkan usulan anggaran & 32 & sangat strategis \\
\hline 7 & $\begin{array}{l}\text { Meningkatkan pelatihan personel yang belum memiliki } \\
\text { sertifikasi; }\end{array}$ & 26 & cukup strategis \\
\hline 8 & Meningkatkan usulan peralatan ke pemerintah pusat; & 25 & $\begin{array}{l}\mathrm{c} \quad \mathrm{u} \mathrm{k} \mathrm{u} p \\
\text { strategis }\end{array}$ \\
\hline 9 & $\begin{array}{l}\text { Melaksanakan forum komunikasi dan koordinasi dengan } \\
\text { perangkat daerah terkait }\end{array}$ & 29 & cukup strategis \\
\hline 10 & $\begin{array}{l}\text { Konsolidasi/penguatan pencegahan, koordinasi sampai } \\
\text { tingkat desa. }\end{array}$ & 32 & $\begin{array}{l}\mathrm{S} \text { a } \mathrm{n} \mathrm{g} \text { a } \mathrm{t} \\
\text { strategis }\end{array}$ \\
\hline
\end{tabular}

Sumber: Diolah Peneliti, 2020

Berdasarkan hasil akumulasi perhitungan dengan menggunakan uji litmus seperti tabel di atas, maka dapat diketahui strategi yang dapat digunakan untuk keberhasilan penerapan e-government dalam meningkatkan kualitas pelayanan publik di Dinas Penanaman Modal dan Pelayanan Terpadu Satu Pintu Provinsi Jambi sebagai berikut.

1. Isu sangat strategis, meliputi:
a. Meningkatkan kerja sama antara satgas dengan masyarakat.
b. Mengadakan pelatihan kepada relawan karhutla
c. Meningkatkan usulan anggaran
d. Konsolidasi / p enguatan pencegahan, koordinasi sampai tingkat desa.

2. Isu cukup strategis, meliputi:
a. Mengadakan dan mengikutsertakan personel pembinaan dan pelatihan.
b. Meningkatkan penegakan hukum
c. Memenuhi standar peraturan Permenhut.
d. Meningkatkan pelatihan personel yang belum memiliki sertifikasi
e. Meningkatkan usulan peralatan ke pemerintah pusat
f. Melaksanakan forum komunikasi dan koordinasi dengan perangkat daerah terkait.

\section{SIMPULAN}

Berdasarkan hasil penelitian dan pembahasan, maka dapat peneliti simpulkan bahwa:

a. Implementasi kebijakan belum dapat diimplementasikan dengan baik dilihat dari enam variabel sebagai berikut.

a) Standar dan sasaran sudah ada, namun standar belum terpenuhi.

b) Sumber daya masih mengalami kekurangan, baik sumber daya manusia, sarana dan prasarana serta anggaran.

c) Karakteristik Organisasi BPBD dalam pencegahan dan pengendalian dapat dikatakan 
belum baik karena belum memiliki SOP (Standar Operasional Prosedurs)

d) Komunikasi antarorganisasi telah dilaksanakan

e) Sikap para pelaksana dapat dikatakan sudah baik,

f) Dukungan aspek sosial, ekonomi dan politik

1. pada aspek sosial telah mendukung, namun masih kekurangan relawan

2. pada aspek ekonomi tidak mendukung

3. pada aspek politik cukup mendukung

Faktor-faktor yang menghambat Implementasi kebijakan:

1. Akses jalan ke kawasan hutan gambut yang tidak tersedia.

2. Kekurangan ketersediaan sumber daya finansial

3. Masih rendahnya kesadaran masyarakat terhadap lingkungan dan pembukaan lahan yang di lakukan secara praktis.

4. Strategi yang sebaiknya digunakan untuk keberhasilan implementasi kebijakan

a. Meningkatkan kerja sama antara satgas dengan masyarakat

b. Mengadakan pelatihan kepada relawan karhutla

c. Meningkatkan usulan anggaran

d. Konsolidasi / penguatan pencegahan, koordinasi sampai tingkat desa.

\section{SARAN}

1. Badan Penanggulangan Bencana Daerah Provinsi perlu memenuhi standar yang telah ditetapkan oleh Peraturan Menteri Lingkungan Hidup dan Kehutanan nomor P.32/MenLHK/Setjen/kum.1/3/2016 dan Peraturan Daerah Provinsi Jambi Nomor 2 Tahun 2016

2. Badan Penanggulangan Bencana Daerah Provinsi perlu meningkatkan sumber daya:

3. Meningkatkan Sumber daya manusia melalui rekruitmen dan peningkatan kualitas sumber daya manusia melalui pelatihan.

4. Meningkatkan Sumber daya non manusia, yaitu peningkatan sarana dan prasarana

5. Badan Penanggulangan Bencana Daerah Provinsi perlu meningkatkan karakteristik organisasi dengan menyusun standar operasional pencegahan dan pengendalian kebakaran hutan dan lahan

6. Meningkatkan dukungan sosial melalui kegiatan-kegiatan yang meningkatkan jumlah relawan karhutla.

7. Meningkatkan dukungan politik untuk mendapatkan kenaikan jumlah anggaran pencegahan dan pengendalian kebakaran hutan dan lahan.

8. Perlu meningkatkan koordinasi antardinas terkait

9. Badan Penanggulangan Bencana Daerah Provinsi perlu meningkatkan sikap para pelaksana yang bekerja berpedoman pada standar operasional prosedur 


\section{DAFTAR PUSTAKA}

Adisasmita, Raharjo. 2011. Manajemen Pemerintahan Daerah. Cetakan Pertama. Graha Ilmu. Yogyakarta

Agustino, Leo. 2008. Dasar-Dasar Kebijakan Publik. Cetakan Kedua. Alfabeta. Bandung Anggara Sahya. 2014. Kebijakan Publik. Pustaka Setia. Bandung

Indriyanto 2010. Ekologi hutan. Jakarta. Bumi Aksara.

Hamdi, Muchlis. 2014, Kebijakan Publik Proses, Analisis, dan Partisipasi. Bogor: Galia Indonesia

Hunger, J David. 2003. Manajemen Strategis. Yogyakarta: Andi.

Ilham dan Rikha, 2015. Pemodelan Kebijakan. Penulisan Literatur IPDN Tahun 2015

Kusumasari, Bevaola. 2014. Manajemen Bencana dan Kapabilitas Pemerintah Lokal. Yogyakarta. Gava Media.

Nasution, Metode Research.2012. Bumi Aksara. Jakarta

Ndraha, Taliziduhu. 2005. Kybernology Sebuah Rekonstruksi Ilmu Pemerintah. Rineka Cipta. Jakarta.

Soehatan Irawan, Metode Penelitian Sosial, 2011, Cetakan Kedelapan Penerbitan PT Remaja Rosdakarya

Sugiyono. 2007. Metode Penelitian Kuantitatif, Kualitatif, dan R \& D. Bandung. Alfabeta

Sugiyono. 2016. Metode Penelitian Kuantitatif, Kualitatif, dan R \& D. Bandung. Alfabeta

Sugiyono. 2017. Metode Penelitian Kuantitatif, Kualitatif, dan R \& D. Bandung. Alfabeta

Syafri, Wirman dan Setyoko, Israwan. 2010. Implementasi Kebijakan Publik dan
Etika Profesi Pamong Praja. Sumedang. Alqaprint

Wasistiono, Sadu. 2015. Metodologi Ilmu Pemerintahan. IPDN Press. Jatinangor

Wasistiono, Sadu. 2017. Perkembangan Ilmu Pemerintahan. Cetakan Pertama, Penerbit IPDN Press

\section{Peraturan Perundang-Undangan}

Undang-Undang Nomor 23 Tahun 2014 tentang Pemerintahan Daerah

Peraturan Menteri Lingkungan Hidup dan Kehutanan Nomor P.12/Menhut-II/2009

Peraturan Daerah Provinsi Jambi Nomor 2 Tahun 2016 tentang Pencegahan dan Pengendalian Kebakaran Hutan dan Lahan.

\section{Sumber Lainnya}

Surat Keputusan Menteri Lingkungan Hidup dan Kehutanan No: 863/MENHUT-II/2014

www. Sipongi. Menlhk. Go.id. rekapitulasi luas kebakaran hutan dan lahan ( $\mathrm{Ha}$ ) Per Provinsi Di Indonesia Tahun 2014-2019

www. Bpbd. Jambiprov. Go.id. Struktur Organisasi Badan Penanggulangan Bencana Daerah Provinsi Jambi.

https://www.Beritasatu.com/nasional/577263/ bencana-asap-63554-warga-jambiterserang-ispa www.iku. Menlhk. Go.id. ISPU K L H K

https://news. Detik.com/berita/d-4748732/ kabut-asap-siswa-mahasiswa-di-jambidiliburkan-mulai-besok

https://www. Cnnindonesia.com/gayahidup/20190918194633-255-431719/ mengenal-ispu-dan-dampaknya-untukkesehatan 
https://www. Beritasatu.com/nasional/591523/ kerusakan-hutan-di-jambi-rugikannegara-rp-12-triliun https://www.Bbc. com/Indonesia/Indonesia-49787843

https://wartanews.Co/fachrori upayapengendalian-karhutla-terusdimaksimalkan/ https://www.inilahjambi.com/fachrori-pimpinrapat-terpadu-penanganan-karhutla-dimuarojambi/

https://www. Cendananews.com/2019/09/ bpbd-jambi-gelontorkan-rp13-miliaroperasional-karhutla. Html 